\title{
PENENTUAN METODE PERAMALAN PERMINTAAN BARANG SETENGAH JADI DI PT. XYZ
}

\author{
Patrick Samuel $^{1)}$, Fransiska Lefta ${ }^{2)}$, Indahsari ${ }^{3)}$, Lina Gozali ${ }^{4)}$ \\ Program Studi Teknik Industri Universitas Tarumanagara \\ e-mail: ${ }^{1)}$ satu2335@gmail.com, ${ }^{2}$ fransiskalefta@yahoo.com, ${ }^{3)}$ indasariho@gmail.com, ${ }^{4}$ ligoz@ymail.com
}

\begin{abstract}
ABSTRAK
PT. XYZ merupakan perusahaan yang bergerak di bidang distribusi barang setengah jadi. Adapun barang yang didistribusikan adalah alumunium yang terbagi menjadi beberapa jenis seperti Alumunium Extrusion, Alumunium Sheet, Alumunium Coil, Alumunium Bordes, dan lain-lain. Permintaan tidak menentu akan banyaknya jenis barang dari beberapa konsumen menyebabkan masalah ketidakpastian bagi perusahaan untuk mengatur jumlah penyimpanan barang digudang. Hal ini menyebabkan beberapa masalah seperti tidak tersedianya barang saat adanya permintaan atau sebaliknya, yaitu penumpukkan barang yang belum dan/atau tidak terjual. Dengan melakukan analisis pada metode peramalan permintaan barang, terdapat 6 jenis barang yang sebaiknya dilakukan peramalan dengan metode linier, 4 jenis barang yang sebaiknya dilakukan peramalan dengan metode kuadratik, dan 1 jenis barang yang sebaiknya dilakukan peramalan dengan metode simple moving average.
\end{abstract}

Kata kunci: Metoda Peramalan, Permintaan, Material.

\section{ABSTRACT}

PT. XYZ which company distributes of semi-finished goods. The distributed items are aluminum which is divided into several types such as Aluminum Extrusion, Aluminum Sheet, Aluminum Coil, Aluminum Bordes, etc. Uncertain demand for different type of goods from some consumers causes uncertainty problem for companies to regulate the amount of storage of goods in warehouses. This causes some problems such as the stockout materials and excess goods in warehouse as an unsold materials. By analyzing the demand forecasting method, there are 6 types of goods that have best forecasting using linear methods, 4 types of goods have best forecasting by quadratic methods, and 1 type of goods has best forecasting using the simple moving average method.

Keywords: Forecast method, Demand, Material.

\section{PENDAHULUAN}

Setiap perusahaan industri di era globalisasi ini dituntut untuk menjadi lebih kreatif dan selalu berkomitmen untuk memenuhi kepuasan konsumen. Hal ini tidak terkecuali dengan perusahaan jasa yang salah satunya adalah perusahaan distributor. Sifat konsumen yang ingin serba cepat pada masa kini membuat perusahaan harus menyusun strategi layanan yang tidak hanya dalam segi kualitas barang, namun juga efisiensi dan efektifitas dalam memasok barang, pemeliharaan barang, dan manajemen pendistribusian yang tepat.

PT. XYZ merupakan perusahaan distributor alumunium yang bertempat di kawasan Cikarang Pusat, Jawa Barat. Alumunium yang dijual oleh PT. XYZ merupakan alumunium yang diperoleh dari beberapa pemasok, dengan kata lain, PT. XYZ tidak memproduksi barangnya sendiri. Ada beberapa tipe alumunium dengan berbegai jenis ukuran yang dijual oleh PT. XYZ. Beragamnya jenis permintaan yang tidak menentu dari berbagai konsumen menyebabkan ketidakpastian jumlah penyimpanan yang harus dilakukan oleh perusahaan. Hal ini berakibat pada ketidakpuasan konsumen karena barang yang diminta tidak tersedia dalam waktu yang diinginkan. Ketidakpuasan konsumen akan menyebabkan konsumen tersebut berhenti membeli produk atau mempengaruhi orang lain untuk tidak membeli produk [1]. Namun apabila perusahaan menyimpan barang terlalu banyak, maka akan menyebabkan pembengkakan biaya simpan atau bahkan barang yang disimpan tidak laku. Oleh sebab itu, perlu dilakukan peramalan atau forecast permintaan konsumen agar PT. $\mathrm{XYZ}$ dapat memperkirakan berapa banyak barang yang harus disimpan. Penentuan 
peramalan dilakukan berdasarkan Metode Simple Moving Average (SMA), Double Moving Average (DMA), Single Exponential Smoothing (SES), Double Exponential Smoothing (DES), Metode Siklik, Metode Linier, dan Metode Kuadratik. Metode Peramalan pada penelitian sebelumnya dapat di gunakan untuk analisis perencanaan produksi [2] dan juga evaluasi sistem distribusi [3].

\section{METODE PENELITIAN}

Penelitian dimulai dengan studi literatur dan observasi lapangan. Selanjutnya melakukan identifikasi masalah berdasarkan observasi yang dilakukan. Masalah yang telah teridentifikasi kemudian dirumuskan. Kemudian dilakukan penentuan tujuan penelitian. Tahap selanjutnya adalah tahap pengumpulan data. Data yang dikumpulkan adalah berupa data permintaan pada PT. XYZ selama 12 bulan. Kemudian melakukan perhitungan peramalan permintaan dengan memperhitungkan error terkecil pada setiap metode peramalan. Kemudian melakukan evaluasi terhadap hasil peramalan tersebut dan membuat kesimpulan serta saran. Berikut ini merupakan diagram alir metodologi penelitian dapat dilihat pada Gambar 1 berikut ini.

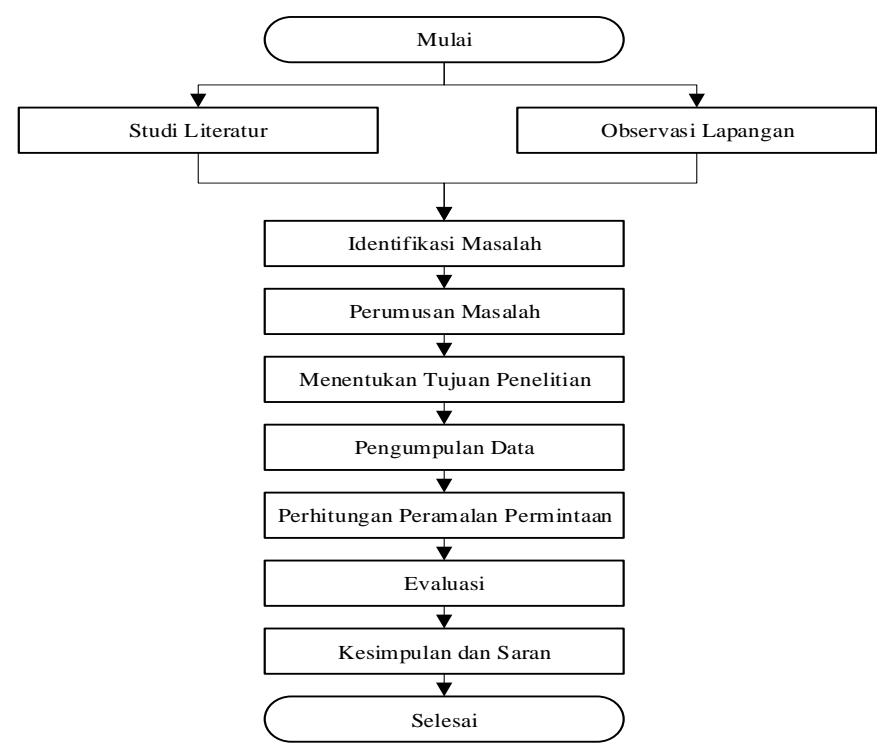

Gambar 1. Diagram Alir Metodologi Penelitian

Peramalan merupakan suatu kegiatan analisa yang dilakukan untuk mengetahui besaran permintaan dimasa mendatang, dengan informasi tersebut maka dapat ditentukan strategi yang tepat untuk perencanaan lebih lanjut [4]. Ramalan dapat bersifat kualitatif maupun kuantitatif [5]. Dalam melakukan peramalan, peneliti menggunakan beberapa metode. Gambar bagan metode peramalan yang digunakan dapat dilihat pada Gambar 2 berikut ini [6].

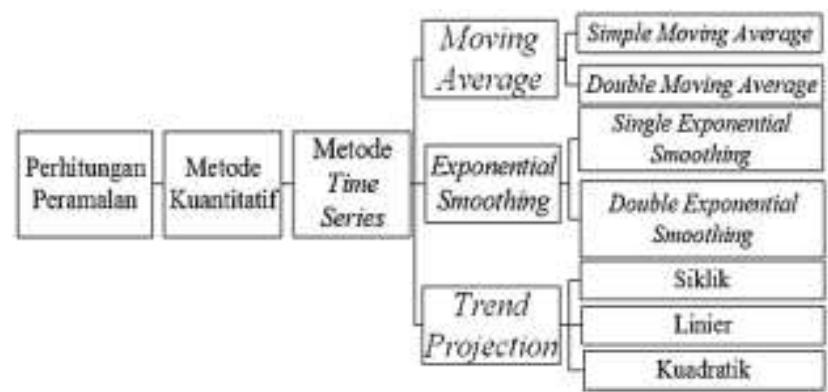

Gambar 2. Bagan Metode Peramalan 


\section{a. Simple Moving Average (SMA)}

Peramalan dengan menggunakan metode ini didasarkan pada proyeksi serial data yang dimuluskan dengan rata-rata bergerak [7]. Rumus SMA adalah sebagai berikut:

$$
F_{t+1}=\frac{\sum x}{n}
$$

\section{b. Double Moving Average (DMA)}

Pada Metode Double Moving Average, dilakukan perhitungan rata-rata bergerak sebanyak dua kali [8]. Kemudian dilanjutkan peramalan dengan menggunakan suatu persamaan tertentu. Rumus menghitung rata-rata bergerak:

$$
M_{t}=\frac{Y_{t}+Y_{t-1}+\cdots+Y_{t-n-1}}{n}
$$

Menentukan besarnya nilai konstanta, slope, dan peramalan dapat menggunakan rumus berikut:

$$
\begin{aligned}
& a_{t}=2 M_{t}-M^{\prime}{ }_{t} \\
& b_{t}=\frac{2}{n-1}\left(M_{t}-M^{\prime}{ }_{t}\right) \\
& \hat{Y}=a_{t}+b_{t} p
\end{aligned}
$$

Dimana:

$M_{t}$ adalah rata-rata bergerak periode $\mathrm{t}$

$\mathrm{n}$ adalah jumlah periode dalam moving average

$Y_{t}$ adalah nilai aktual periode $\mathrm{t}$

$\mathrm{P}$ adalah jumlah periode yang ingin diramalkan

\section{c. Single Exponential Smoothing (SES)}

Metode Exponential Smoothing adalah teknik peramalan rata-rata bergerak dengan pembobotan dimana data diberi bobot oleh sebuah fungsi exponential [9]. Rumus exponential smoothing adalah sebagai berikut:

$$
F_{t+1}=\alpha X_{t}+(1-\alpha) F_{t-1}
$$

Dimana:

$F_{t+1}$ adalah peramalan untuk periode $\mathrm{t}+1$

$X_{t}$ adalah nilai real periode ke $\mathrm{t}$

$\alpha$ adalah bobot yang menunjukkan konstanta smoothing $(0<\alpha<1)$

$F_{t-1}$ adalah peramalan untuk period ke $\mathrm{t}-1$

\section{d. Double Exponential Smoothing (DES)}

Parameter yang digunakan pada Metode Double Exponential Smoothing yaitu $\alpha$, yang memiliki nilai antara 0 dan 1 . Jika data yang digunakan semakin banyak dalam perhitungan peramalannya maka percentage error peramalannya akan semakin kecil, begitu juga sebaliknya. Berikut merupakan tahap untuk melakukan perhitungan peramalan dengan menggunakan Double Exponential Smoothing.

Menentukan smoothing pertama.

$$
S^{\prime}{ }_{t}=\alpha X_{t}+(1-\alpha) S^{\prime}{ }_{t-1}
$$

Menentukan smoothing kedua.

$$
S^{\prime \prime}{ }_{t}=\alpha S_{t}^{\prime}+(1-\alpha){S^{\prime \prime}}_{t-1}
$$

Menentukan besarnya konstanta a.

$$
a_{t}=2 S^{\prime}{ }_{t}-S^{\prime \prime}{ }_{t}
$$


Menentukan besarnya slope.

$$
b_{t}=\frac{\alpha}{1-\alpha}\left(S^{\prime}{ }_{t}-S^{\prime \prime}{ }_{t}\right)
$$

Menentukan nilai peramalan,

$$
F_{t+p}=\hat{Y}_{t+p}=a_{t}+b_{t} p
$$

e. Metode Siklik

Pola data siklis terjadi bilamana datanya dipengaruhi oleh fluktuasi ekonomi jangka panjang seperti yang berhubungan dengan siklus bisnis. Rumus yang digunakan adalah sebagai berikut:

$$
\begin{aligned}
& D^{\prime}{ }_{i}=a+b_{t} \\
& S F_{i}=\left(S_{i}\right)\left(D^{\prime}{ }_{t}\right) \\
& S_{i}=\frac{D_{i}}{\sum D} \\
& b=\frac{n \sum t d_{t}-\sum t \sum d_{t}}{n \sum t^{2}-\left(\sum t\right)^{2}} \\
& a=\frac{\sum d_{t}-b \sum t}{n}
\end{aligned}
$$

\section{f. Metode Regresi Linier}

Regresi Linier dapat digunakan untuk mengembangkan model peramalan kausal serta model peramalan waktu [10]. Rumus perhitungan Metode Linier adalah sebagai berikut:

$$
\begin{aligned}
& \hat{y}=a+b x \\
& a=\frac{\sum y-b \sum x}{n} \\
& b=\frac{n \sum x y-\sum x \sum y}{n \sum x^{2}-\left(\sum x\right)^{2}} \\
& \bar{X}=\frac{\sum x}{n} \\
& \bar{Y}=\frac{\sum y}{n}
\end{aligned}
$$

g. Metode Kuadratik

Metode ini menggunakan data secara acak berfluktuasi membentuk kurva kuadratik. Rumus yang digunakan pada Metode Kuadratik adalah sebagai berikut:

$$
\begin{aligned}
& Y_{t}=a+b t+c t^{2} \\
& a=\frac{\sum Y-c \sum t^{2}}{n} \\
& b=\frac{\sum t Y}{\sum t^{2}} \\
& c=\frac{n \sum t^{2} y-\sum t^{2} \sum Y}{n \sum t^{4}-\left(\sum t^{2}\right)^{2}}
\end{aligned}
$$

Langkah berikutnya menentukan metode peramalan yang akan digunakan. Metode peramalan yang digunakan adalah yang memiliki nilai kesalahan terkecil, Ada beberapa 
teknik perhitungan kesalahan peramalan, Tiga dari perhitungan yang paling sering digunakan, yaitu [11]:

a. Mean Absolute Deviation (MAD)

Merupakan rata-rata nilai absolut kesalahan peramalan. Rumus MAD:

$$
\mathrm{MAD}=\frac{\sum \mid \text { aktual }- \text { peramalan } \mid}{n}
$$

Keterangan:

$\mathrm{n}$ adalah jumlah data

b. Mean Square Error (MSE)

Merupakan metode alternative dalam mengevaluasi suatu teknik peramalan. Semakin kecil rata-rata jumlah kuadrat nilai MSE, semakin kecil pula kesalahan peramalan menggunakan teknik tersebut [12]. Rumus MSE:

$$
\text { MSE }=\frac{(\text { aktual }- \text { peramalan })^{2}}{n}
$$

Keterangan:

$\mathrm{n}$ adalah jumlah periode

c. Mean Absolute Percent Error (MAPE)

MAPE merupakan indikator kesalahan peramalan yang menunjukkan rata-rata persenasi mutlak kesalahan peramalan. Rumus MAPE:

$$
\text { MAPE: } \frac{\left.\sum \text { (aktual-peramalan }\right)}{n} \mathrm{x} 100 \%
$$

\section{HASIL DAN PEMBAHASAN}

Jumlah pemintaan selama dua belas bulan pada PT. XYZ untuk setiap jenis barang

\begin{tabular}{|c|c|c|c|c|c|c|c|c|c|c|c|c|c|}
\hline No & Jenis Barang & Januari & Februari & Maret & April & Mei & Juni & Juli & Agustus & September & Oktober & November & Desember \\
\hline 3 & EX0560AKWH & 320 & 35 & 117 & 31 & 88 & 191 & 30 & 13 & 132 & 28 & 113 & 7 \\
\hline 4 & EX9055AXBL & 139 & 162 & 288 & 164 & 75 & 29 & 0 & 63 & 176 & 15 & 20 & 56 \\
\hline 6 & EXH1123AKCA & 0 & 33 & 8 & 25 & 150 & 0 & 20 & 113 & 40 & 12 & 10 & 0 \\
\hline 7 & EXS4040BMJC & 0 & 83 & 0 & 5 & 0 & 2 & 0 & 100 & 57 & 0 & 100 & 0 \\
\hline 8 & EXU1212AXBL & 230 & 30 & 100 & 167 & 0 & 130 & 70 & 15 & 216 & 25 & 370 & 145 \\
\hline 11 & PA120322IN & 66 & 155 & 232 & 117 & 252 & 67 & 186 & 334 & 80 & 72 & 212 & 48 \\
\hline
\end{tabular}
dapat dilihat pada Tabel 1 .

Tabel 1. Data Permintaan Barang PT. XYZ

Berdasarkan data pada Tabel 1, dilakukan perhitungan MAD, MSE, MAPE, dan AVE untuk menentukan metode peramalan yang memiliki error paling kecil untuk setiap jenis barang yang diminta pada PT. XYZ. Metode tersebut nantinya merupakan metode yang digunakan dalam peramalan. Hasil perhitungan nilai error peramalan dengan menggunakan setiap jenis metode peramalan untuk jenis barang BD121183ST dapat dilihat

\begin{tabular}{|c|c|c|c|c|c|c|c|c|c|c|c|c|c|c|c|}
\hline Error & SMA-2 & DMA-2 & \multicolumn{5}{|c|}{ SES } & \multicolumn{5}{|c|}{ DES } & Siklik & Linier & Kuadratik \\
\hline MAD & 20.13 & 27.5 & 19.72 & 19.12 & 18.60 & 17.90 & 17.13 & 19.73 & 18.15 & 17.18 & 22.72 & 29.76 & 248.3 & 13.51 & 13.55 \\
\hline MSE & 569.3 & 1001.9 & 418.4 & 422.8 & 437.7 & 469.1 & 527.1 & 421.3 & 482.6 & 614.9 & 848.4 & 1343.1 & 128826 & 243.6 & 243.8 \\
\hline MAPE & 97.92 & 147.77 & 86.01 & 98.99 & 99.43 & 92.35 & 83.74 & 104.4 & 115.7 & 102.5 & 127.3 & 138.2 & 744.7 & 68.42 & 69.37 \\
\hline
\end{tabular}
pada Tabel 2.

Tabel 2. Error Peramalan Permintaan Jenis Barang BD121183ST 
Berdasarkan perhitungan error dari setiap peramalan permintaan jenis barang BD121183ST, metode peramalan yang memiliki error terkecil pada perhitungan MAD adalah Metode Linier yaitu sebesar 13.51, error terkecil pada perhitungan MSE adalah Metode Linier yaitu sebesar 243.64, error terkecil pada perhitungan MAPE adalah Metode Linier yaitu sebesar 68.42, dan error terkecil pada perhitungan AVE adalah Metode Linier yaitu sebesar 108.522342. Sehingga metode peramalan terbaik untuk melakukan peramalan permintaan jenis barang BD121183ST adalah Metode Linier dengan persamaan $Y^{\prime}(t)=41.14+3.17(t)$. Hasil peramalan permintaan jenis barang BD121183ST untuk periode 12 bulan ke depan dengan menggunakan Metode Linier dapat dilihat pada Tabel 3.

Tabel 3. Peramalan Permintaan 12 Bulan ke Depan untuk Jenis Barang BD121183ST

\begin{tabular}{ccccccccccccc}
\hline Bulan ke- & 13 & 14 & 15 & 16 & 17 & 18 & 19 & 20 & 21 & 22 & 23 & 24 \\
\hline Hasil Peramalan & 82.4 & 85.5 & 88.7 & 91.9 & 95 & 98.2 & 101 & 105 & 108 & 111 & 114 & 117.2 \\
\hline
\end{tabular}

Hasil perhitungan nilai error peramalan dengan menggunakan setiap jenis metode peramalan untuk jenis barang BD481226ST dapat dilihat pada Tabel 4.

Tabel 4. Error Peramalan Permintaan Jenis Barang BD481226ST

\begin{tabular}{|c|c|c|c|c|c|c|c|c|c|c|c|c|c|c|c|}
\hline Error & SMA-2 & DMA-2 & \multicolumn{5}{|c|}{ SES } & \multicolumn{5}{|c|}{ DES } & Siklik & Linier & Kuadratik \\
\hline MAD & 7.71 & 9.42 & 10.56 & 8.91 & 8.40 & 8.62 & 9.69 & 10.45 & 9.65 & 11 & 9.11 & 17.22 & 65.33 & 8.72 & 23.46 \\
\hline MSE & 117.2 & 163.8 & 168.8 & 135.8 & 136.1 & 150.3 & 179 & 161 & 165.4 & 209 & 144.2 & 525.7 & 7600 & 93.68 & 101.19 \\
\hline MAPE & 29.89 & 50.09 & 49.68 & 37.13 & 28.43 & 25.67 & 33.05 & 48.42 & 31.61 & 39.19 & 12.69 & 79.29 & 344.5 & 31.03 & 16.86 \\
\hline
\end{tabular}

Berdasarkan perhitungan error dari setiap peramalan permintaan jenis barang BD481226ST, metode peramalan yang memiliki error terkecil pada perhitungan MAD adalah Metode Linier yaitu sebesar 8.72, error terkecil pada perhitungan MSE adalah Metode Linier yaitu sebesar 93.68, error terkecil pada perhitungan MAPE adalah Metode DES $\alpha=0,7$ yaitu sebesar 12.69, dan error terkecil pada perhitungan AVE adalah Metode Linier yaitu sebesar 44.4806633. Sehingga metode peramalan terbaik untuk melakukan peramalan permintaan jenis barang BD481226ST adalah Metode Linier dengan persamaan $Y^{\prime}(t)=9.697+0.329(t)$. hasil peramalan permintaan jenis barang BD121183ST untuk periode 12 bulan ke depan dengan menggunakan Metode Linier dapat dilihat pada Tabel 5.

Tabel 5. Peramalan Permintaan 12 Bulan ke Depan untuk Jenis Barang BD481226ST

\begin{tabular}{ccccccccccccc}
\hline Bulan ke- & 13 & 14 & 15 & 16 & 17 & 18 & 19 & 20 & 21 & 22 & 23 & 24 \\
\hline Hasil Peramalan & 14 & 14 & 15 & 15 & 15 & 16 & 16 & 16 & 17 & 17 & 17 & 18 \\
\hline
\end{tabular}

Hasil perhitungan nilai error peramalan dengan menggunakan setiap jenis metode peramalan untuk jenis barang EX0560AKWH dapat dilihat pada Tabel 6.

Tabel 6. Error Peramalan Permintaan Jenis Barang EX0560AKWH

\begin{tabular}{|c|c|c|c|c|c|c|c|c|c|c|c|c|c|c|c|}
\hline \multirow{2}{*}{ Error } & \multirow{2}{*}{ SMA-2 } & \multirow{2}{*}{ DMA-2 } & \multicolumn{5}{|c|}{ SES } & \multicolumn{5}{|c|}{ DES } & \multirow{2}{*}{ Siklik } & \multirow{2}{*}{ Linier } & \multirow{2}{*}{ Kuadratik } \\
\hline & & & $\alpha=0,1$ & $\alpha=0,3$ & $\alpha=0,5$ & $\alpha=0,7$ & $\alpha=0,9$ & $\alpha=0,1$ & $\alpha=0,3$ & $\alpha=0,5$ & $\alpha=\mathbf{0 , 7}$ & $\alpha=0,9$ & & & \\
\hline MAD & $\begin{array}{l}7.71 \\
\end{array}$ & $\begin{array}{l}41.48 \\
\end{array}$ & 41.48 & 104.2 & 93.22 & 93.37 & $\begin{array}{l}103.7 \\
\end{array}$ & 92.44 & 71.70 & 91.23 & 73.86 & 160.5 & $\begin{array}{l}1702.8 \\
\end{array}$ & 66.5 & 63.24 \\
\hline MSE & 117.2 & 2403 & 2403 & 15442 & 13278 & 13549 & 15054 & 11289 & 6873 & 10234 & 6451 & 30696 & 7783706 & 6203 & 3428.3 \\
\hline MAPE & 29.89 & 214.2 & 214.2 & 381.3 & 334.4 & 334.6 & 351.8 & 339.9 & 193.2 & 277.1 & 245.6 & 553.7 & 1840.4 & 160.6 & 185.36 \\
\hline AVE & 51.61 & 886.2 & 886.2 & 5309.2 & 4568.8 & 4659 & 5169.8 & 3907 & 2379.3 & 3534.1 & 2256.8 & 10470 & 2595748 & 2143.3 & 1225.64 \\
\hline
\end{tabular}

Berdasarkan perhitunggan error dari setiap peramalan permintaan jenis barang EX0560AKWH, metode peramalan yang memiliki error terkecil pada perhitungan MAD dengan nilai error sebesar 7.71, MSE dengan nilai error sebesar 117.23, MAPE dengan nilai error sebesar 29.89, dan AVE dengan nilai error sebesar 51.61 adalah metode SMA2. Sehingga metode peramalan terbaik untuk melakukan peramalan permintaan jenis barang EX0560AKWH adalah menggunakan Metode SMA-2. Hasil peramalan permintaan 
jenis barang EX0560AKWH untuk periode 12 bulan ke depan dengan menggunakan Metode SMA-2 dapat dilihat pada Tabel 7.

Tabel 7. Peramalan Permintaan 12 Bulan ke Depan untuk Jenis Barang EX0560AKWH

\begin{tabular}{ccccccccccccc}
\hline Bulan ke- & 13 & 14 & 15 & 16 & 17 & 18 & 19 & 20 & 21 & 22 & 23 & 24 \\
\hline Hasil Peramalan & 20 & 20 & 20 & 20 & 20 & 20 & 20 & 20 & 20 & 20 & 20 & 20 \\
\hline
\end{tabular}

Hasil perhitungan nilai error peramalan dengan menggunakan setiap jenis metode peramalan untuk jenis barang EX9055AXBL dapat dilihat pada Tabel 8.

Tabel 8. Error Peramalan Permintaan Jenis Barang EX9055AXBL

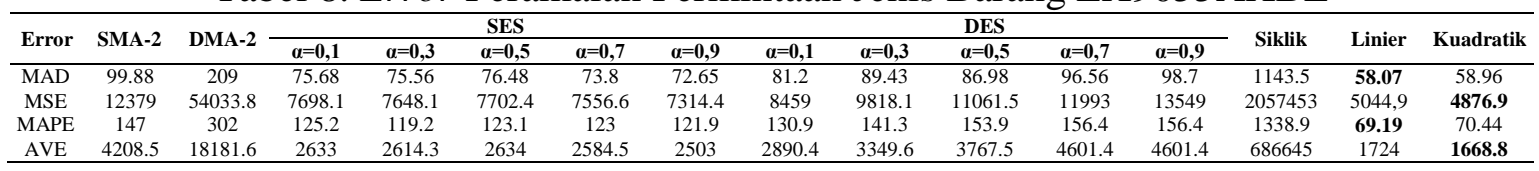

Berdasarkan perhitungan error dari setiap peramalan permintaan jenis barang EX9055AXBL, metode peramalan yang memiliki error terkecil pada perhitungan MAD adalah Metode Linier dengan nilai error sebesar 58.07, error terkecil pada perhitungan MSE adalah Metode Kuadratik dengan nilai error sebesar 4876.86, error terkecil pada perhitungan MAPE adalah Metode Linier dengan nilai error sebesar 69.19, dan error terkecil pada perhitungan AVE adalah Metode Kuadratik yaitu sebesar 1668.75. Sehingga metode peramalan terbaik untuk melakukan peramalan permintaan jenis barang EX9055AXBL adalah Metode Kuadratik dengan persamaan $Y^{\prime}(t)=218.93-$ $26.91(t)+1.23\left(t^{2}\right)$. Hasil peramalan permintaan jenis barang EX9055AXBL untuk periode 12 bulan ke depan dengan menggunakan Metode Kuadratik dapat dilihat pada Tabel 9.

Tabel 9. Peramalan Permintaan 12 Bulan ke Depan untuk Jenis Barang EX9055AXBL

\begin{tabular}{ccccccccccccc}
\hline Bulan ke- & 13 & 14 & 15 & 16 & 17 & 18 & 19 & 20 & 21 & 22 & 23 & 24 \\
\hline Hasil Peramalan & 77 & 83 & 92 & 102 & 117 & 133 & 152 & 173 & 196 & 222 & 251 & 282 \\
\hline
\end{tabular}

Hasil perhitungan nilai error peramalan dengan menggunakan setiap jenis metode peramalan untuk jenis barang BD 121183ST dapat dilihat pada Tabel 10.

Tabel 10. Error Peramalan Permintaan Jenis Barang EXH2550ACBR

\begin{tabular}{|c|c|c|c|c|c|c|c|c|c|c|c|c|c|c|c|}
\hline Error & SMA-2 & DMA-2 & \multicolumn{5}{|c|}{ SES } & \multicolumn{5}{|c|}{ DES } & Siklik & Linier & Kuadratik \\
\hline MSE & 490 & 322.65 & 982.2 & 535.7 & 465.1 & 461.1 & 481.8 & 362.6 & 239 & 329.3 & 502.2 & 762.9 & 614.6 & 220.3 & 212.67 \\
\hline MAPE & 35.03 & 30.90 & 51.25 & 14.64 & 16.71 & 24.98 & 31.46 & 22.12 & 43.78 & 50.7 & 59.74 & 72.24 & 63.5 & 20.97 & 22.86 \\
\hline
\end{tabular}

Berdasarkan perhitungan error dari setiap peramalan permintaan jenis barang EXH2550ACBR, metode peramalan yang memiliki error terkecil pada perhitungan MAD adalah Metode DMA-2 dengan nilai error sebesar 10.90, error terkecil pada perhitungan MSE adalah Metode Kuadratik dengan nilai error sebesar 212.67, error terkecil pada perhitungan MAPE adalah Metode Linier dengan nilai error sebesar 20.97, dan error terkecil pada perhitungan AVE adalah Metode Kuadratik yaitu sebesar 82.65. Sehingga metode peramalan terbaik untuk melakukan peramalan permintaan jenis barang EXH2550ACBR adalah Metode Kuadratik dengan persamaan $Y^{\prime}(t)=3.17-4.86(t)+$ $0.26\left(t^{2}\right)$. Hasil peramalan permintaan jenis barang EXH2550ACBR untuk periode 12 bulan ke depan dengan menggunakan Metode Kuadratik dapat dilihat pada Tabel 11. 
Tabel 11. Peramalan Permintaan 12 Bulan ke Depan untuk Jenis Barang EXH2550ACBR

\begin{tabular}{ccccccccccccc}
\hline Bulan ke- & 13 & 14 & 15 & 16 & 17 & 18 & 19 & 20 & 21 & 22 & 23 & 24 \\
\hline Hasil Peramalan & 12 & 15 & 17 & 21 & 24 & 28 & 33 & 39 & 44 & 51 & 57 & 65 \\
\hline
\end{tabular}

Hasil perhitungan nilai error peramalan dengan menggunakan setiap jenis metode peramalan untuk jenis barang EXH1123AKCA dapat dilihat pada Tabel 12.

Tabel 12. Error Peramalan Permintaan Jenis Barang EXH1123AKCA

\begin{tabular}{|c|c|c|c|c|c|c|c|c|c|c|c|c|c|c|c|}
\hline Error & SMA-2 & DMA-2 & \multicolumn{5}{|c|}{ SES } & \multicolumn{5}{|c|}{ DES } & Siklik & Linier & Kuadratik \\
\hline MAD & 45.25 & 51.02 & 35.63 & 41.58 & 45.1 & 47.29 & 49.75 & 41.33 & 50.78 & 53.62 & 68.23 & 86.19 & 654.5 & 33.66 & 45.19 \\
\hline MSE & 3794.5 & 5770.5 & 3007.7 & 3028.4 & 3356.3 & 3897 & 4620 & 3214 & 3967.5 & 5548.6 & 8348.3 & 12719 & 1500761 & 1395.7 & 1613.5 \\
\hline MAPE & 120.3 & 116.1 & 70.81 & 101.2 & 110.5 & 107.4 & 102.6 & 100.6 & 136 & 115.1 & 157.2 & 231.8 & 1177.4 & 85.62 & 82.96 \\
\hline
\end{tabular}

Berdasarkan perhitunggan error dari setiap peramalan permintaan jenis barang EXH1123AKCA, metode peramalan yang memiliki error terkecil pada perhitungan MAD dengan nilai error sebesar 33.66, MSE dengan nilai error sebesar 1395.65, MAPE dengan nilai error sebesar 82.96, dan AVE dengan nilai error sebesar 504.98 adalah Metode Linier. Sehingga metode peramalan terbaik untuk melakukan peramalan permintaan jenis barang EXH1123AKCA adalah menggunakan Metode Linier dengan persamaan $Y^{\prime}(t)=$ $38.68-0.68(t)$. Hasil peramalan permintaan jenis barang EXH1123AKCA untuk periode 12 bulan ke depan dengan menggunakan Metode Linier dapat dilihat pada Tabel 13.

Tabel 13. Peramalan Permintaan 12 Bulan ke Depan untuk Jenis Barang EXH1123AKCA

\begin{tabular}{ccccccccccccc}
\hline Bulan ke- & 13 & 14 & 15 & 16 & 17 & 18 & 19 & 20 & 21 & 22 & 23 & 24 \\
\hline Hasil Peramalan & 30 & 29 & 28 & 28 & 27 & 26 & 26 & 25 & 24 & 24 & 23 & 22 \\
\hline
\end{tabular}

Hasil perhitungan nilai error peramalan dengan menggunakan setiap jenis metode peramalan untuk jenis barang EXS4040BMJC dapat dilihat pada Tabel 14.

Tabel 14. Error Peramalan Permintaan Jenis Barang EXS4040BMJC

\begin{tabular}{|c|c|c|c|c|c|c|c|c|c|c|c|c|c|c|c|}
\hline Error & SMA-2 & DMA-2 & \multicolumn{5}{|c|}{ SES } & \multicolumn{5}{|c|}{ DES } & Siklik & Linier & Kuadratik \\
\hline MAD & 35.79 & 34.73 & 34.14 & 39.03 & 41.47 & 45.07 & 49.68 & 32.88 & 40.67 & 51.67 & 64.38 & 80.28 & 440.8 & 35.73 & 35.7 \\
\hline MSE & 2654.4 & 2430.6 & 2332.4 & 2434 & 2814.5 & 3330.5 & 4022 & 1826.2 & 2753 & 4219 & 6537.4 & 10391 & 583639 & 1604.1 & 1601.99 \\
\hline MAPE & 86.48 & 103.7 & 56.88 & 85.06 & 74.38 & 53.07 & 43.17 & 84.55 & 90.45 & 87.29 & 109.3 & 196.4 & 665.7 & 156.8 & 148.9 \\
\hline
\end{tabular}

Berdasarkan perhitungan error dari setiap peramalan permintaan jenis barang EXS4040BMJC, metode peramalan yang memiliki error terkecil pada perhitungan MAD adalah Metode DMA-2 dengan nilai error sebesar 34.73, error terkecil pada perhitungan MSE adalah Metode Kuadratik dengan nilai error sebesar 1601.99, error terkecil pada perhitungan MAPE adalah metode SES $\alpha=0.9$ dengan nilai error sebesar 43.17, dan error terkecil pada perhitungan AVE adalah Metode Kuadratik yaitu sebesar 595.52. Sehingga metode peramalan terbaik untuk melakukan peramalan permintaan jenis barang EXS4040BMJC adalah Metode Kuadratik dengan persamaan $Y^{\prime}(t)=16.93+0.7(t)+$ $0.14\left(t^{2}\right)$. Hasil peramalan permintaan jenis barang EXS4040BMJC untuk periode 12 bulan ke depan dengan menggunakan Metode Kuadratik dapat dilihat pada Tabel 15.

Tabel 15. Peramalan Permintaan 12 Bulan ke Depan untuk Jenis Barang EXS4040BMJC

\begin{tabular}{ccccccccccccc}
\hline Bulan ke- & 13 & 14 & 15 & 16 & 17 & 18 & 19 & 20 & 21 & 22 & 23 & 24 \\
\hline Hasil Peramalan & 16 & 20 & 25 & 30 & 35 & 41 & 47 & 53 & 60 & 66 & 73 & 81 \\
\hline
\end{tabular}

Hasil perhitungan nilai error peramalan dengan menggunakan setiap jenis metode peramalan untuk jenis barang EXU1212AXBL dapat dilihat pada Tabel 16. 
Tabel 16. Error Peramalan Permintaan Jenis Barang EXU1212AXBL

\begin{tabular}{|c|c|c|c|c|c|c|c|c|c|c|c|c|c|c|c|}
\hline \multirow{2}{*}{ Error } & \multirow{2}{*}{ SMA-2 } & \multirow{2}{*}{ DMA-2 } & \multicolumn{5}{|c|}{ SES } & \multicolumn{5}{|c|}{ DES } & \multirow[b]{2}{*}{ Siklik } & \multirow[b]{2}{*}{ Linier } & \multirow[b]{2}{*}{ Kuadratik } \\
\hline & & & $\alpha=0,1$ & $\alpha=0,3$ & $\alpha=0,5$ & $\alpha=0,7$ & $\alpha=0,9$ & $\alpha=0,1$ & $\alpha=0,3$ & $\alpha=0,5$ & $\alpha=0,7$ & $\alpha=0,9$ & & & \\
\hline MAD & 102.2 & 8921.8 & 116.2 & 92.75 & 104.2 & 116.6 & 131.5 & 91.53 & 103.7 & 143.6 & 190.9 & 244.8 & 1820.6 & 83.07 & 80.51 \\
\hline MSE & 16303 & 18908495 & 18144 & 14319 & 15815 & 19086 & 24367 & 15284.1 & 18182 & 27478 & 46286 & 81000.5 & 7861731 & 10505.4 & 8546.4 \\
\hline MAPE & 120.6 & 11493.3 & 234 & 110.6 & 129.4 & 144.3 & 161 & 127 & 102.7 & 162.3 & 221.4 & 274.8 & 1284.9 & 149.7 & 137.7 \\
\hline
\end{tabular}

Berdasarkan perhitungan error dari setiap peramalan permintaan jenis barang EXU1212AXBL, metode peramalan yang memiliki error terkecil pada perhitungan MAD adalah Metode Kuadratik dengan nilai error sebesar 80.51, error terkecil pada perhitungan MSE adalah Metode Kuadratik dengan nilai error sebesar 8546.44, error terkecil pada perhitungan MAPE adalah Metode DES $\alpha=0.3$ dengan nilai error sebesar 102.71, dan error terkecil pada perhitungan AVE adalah Metode Kuadratik yaitu sebesar 2921.56. Sehingga metode peramalan terbaik untuk melakukan peramalan permintaan jenis barang EXU1212AXBL adalah Metode Kuadratik dengan persamaan $Y^{\prime}(t)=210.55-$ $48.16(t)+4.20\left(t^{2}\right)$. Hasil peramalan permintaan jenis barang EXU1212AXBL untuk periode 12 bulan ke depan dengan menggunakan Metode Kuadratik dapat dilihat pada Tabel 17.

Tabel 17. Peramalan Permintaan 12 Bulan ke Depan untuk Jenis Barang EXU1212AXBL

\begin{tabular}{ccccccccccccc}
\hline Bulan ke- & 13 & 14 & 15 & 16 & 17 & 18 & 19 & 20 & 21 & 22 & 23 & 24 \\
\hline Hasil Peramalan & 294 & 360 & 433 & 515 & 606 & 704 & 812 & 927 & 1051 & 1184 & 1325 & 1474 \\
\hline
\end{tabular}

Hasil perhitungan nilai error peramalan dengan menggunakan setiap jenis metode peramalan untuk jenis barang PA120468ST dapat dilihat pada Tabel 18.

Tabel 18. Error Peramalan Permintaan Jenis Barang PA120468ST

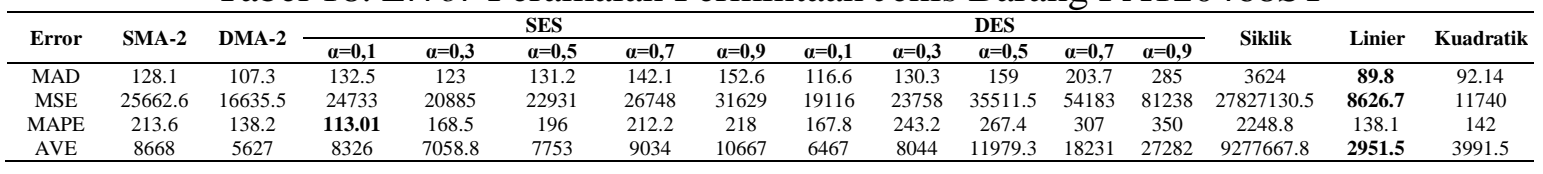

Berdasarkan perhitungan error dari setiap peramalan permintaan jenis barang PA120468ST, metode peramalan yang memiliki error terkecil pada perhitungan MAD adalah Metode Linier dengan nilai error sebesar 89.80, error terkecil pada perhitungan MSE adalah Metode Linier dengan nilai error sebesar 8626.70, error terkecil pada perhitungan MAPE adalah Metode SES $\alpha=0.1$ dengan nilai error sebesar 113.01, dan error terkecil pada perhitungan AVE adalah Metode Linier yaitu sebesar 2951,54. Sehingga metode peramalan terbaik untuk melakukan peramalan permintaan jenis barang PA120468ST adalah Metode Linier dengan persamaan $Y^{\prime}(t)=112.924+5.63986(t)$. Hasil peramalan permintaan jenis barang PA120468ST untuk periode 12 bulan ke depan dengan menggunakan Metode Linier dapat dilihat pada Tabel 19.

Tabel 19. Peramalan Permintaan 12 Bulan ke Depan untuk Jenis Barang PA120468ST

\begin{tabular}{ccccccccccccc}
\hline Bulan ke- & 13 & 14 & 15 & 16 & 17 & 18 & 19 & 20 & 21 & 22 & 23 & 24 \\
\hline Hasil Peramalan & 186 & 192 & 198 & 203 & 209 & 214 & 220 & 226 & 231 & 237 & 243 & 248.3 \\
\hline
\end{tabular}

Hasil perhitungan nilai error peramalan dengan menggunakan setiap jenis metode peramalan untuk jenis barang PA1200398IN dapat dilihat pada Tabel 20.

Tabel 20. Error Peramalan Permintaan Jenis Barang PA1200398IN

\begin{tabular}{|c|c|c|c|c|c|c|c|c|c|c|c|c|c|c|c|}
\hline Error & SMA-2 & DMA-2 & \multicolumn{5}{|c|}{ SES } & \multicolumn{5}{|c|}{ DES } & Siklik & Linier & Kuadratik \\
\hline MAD & 205.3 & 230.3 & 95.59 & 88.8 & 89.56 & 89.38 & 90.22 & 86.72 & 94.82 & 96.48 & 115.6 & 136.1 & 5595.8 & 59.83 & 65.85 \\
\hline MSE & 58312 & 61232.8 & 16370 & 11929 & 11257 & 11445 & 12091 & 13520.8 & 12969 & 15076.8 & 19230.5 & 26150 & 47595709 & 4773.8 & 5602.63 \\
\hline MAPE & 13796 & 131.4 & 39.63 & 44.16 & 48.39 & 50.26 & 51.48 & 39.78 & 54.64 & 56.7 & 63.69 & 70.2 & 276633 & 52.48 & 43.55 \\
\hline
\end{tabular}


Berdasarkan perhitungan error dari setiap peramalan permintaan jenis barang PA1200398IN, metode peramalan yang memiliki error terkecil pada perhitungan MAD adalah Metode Linier dengan nilai error sebesar 59,83, error terkecil pada perhitungan MSE adalah Metode Linier dengan nilai error sebesar 4773,80, error terkecil pada perhitungan MAPE adalah Metode SES $\alpha=0,1$ dengan nilai error sebesar 39,63, dan error terkecil pada perhitungan AVE adalah Metode Linier yaitu sebesar 1628,70. Sehingga metode peramalan terbaik untuk melakukan peramalan permintaan jenis barang PA1200398IN adalah Metode Linier dengan persamaan $Y^{\prime}(t)=197.31818-$ $0.9335664(t)$. Hasil peramalan permintaan jenis barang PA1200398IN untuk periode 12 bulan ke depan dengan menggunakan Metode Linier dapat dilihat pada Tabel 21.

Tabel 21. Peramalan Permintaan 12 Bulan ke Depan untuk Jenis Barang PA1200398IN

\begin{tabular}{ccccccccccccc}
\hline Bulan ke- & 13 & 14 & 15 & 16 & 17 & 18 & 19 & 20 & 21 & 22 & 23 & 24 \\
\hline Hasil Peramalan & 185 & 184 & 183 & 182 & 181 & 181 & 180 & 179 & 178 & 177 & 176 & 175 \\
\hline
\end{tabular}

Hasil perhitungan nilai error peramalan dengan menggunakan setiap jenis metode peramalan untuk jenis barang PA120322IN dapat dilihat pada Tabel 22.

Tabel 22. Error Peramalan Permintaan Jenis Barang PA120322IN

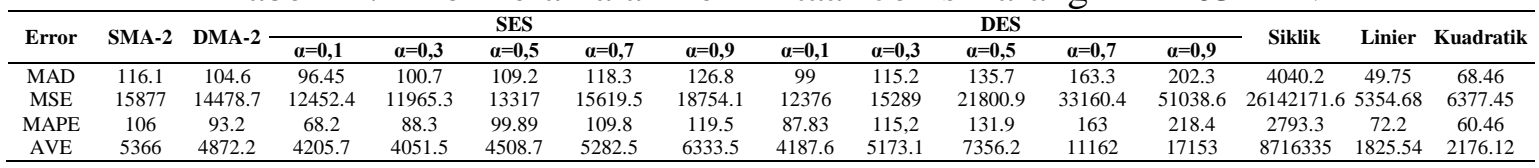

Berdasarkan perhitunggan error dari setiap peramalan permintaan jenis barang PA120322IN, metode peramalan yang memiliki error terkecil pada perhitungan MAD dengan nilai error sebesar 49,75, MSE dengan nilai error sebesar 5354,68, MAPE dengan nilai error sebesar 60,46, dan AVE dengan nilai error sebesar 1825,54 adalah Metode Linier. Sehingga metode peramalan terbaik untuk melakukan peramalan permintaan jenis barang PA120322IN adalah menggunakan Metode Linier dengan $Y^{\prime}(t)=165.9545455-$ 2.185314685 $(t)$. Hasil peramalan permintaan jenis barang PA120322IN untuk periode 12 bulan ke depan dengan menggunakan Metode Linier.

Tabel 23. Peramalan Permintaan 12 Bulan ke Depan untuk Jenis Barang PA120322IN

\begin{tabular}{ccccccccccccc}
\hline Bulan ke- & 13 & 14 & 15 & 16 & 17 & 18 & 19 & 20 & 21 & 22 & 23 & 24 \\
\hline Hasil Peramalan & 138 & 135 & 133 & 131 & 129 & 127 & 124 & 122 & 120 & 118 & 116 & 114 \\
\hline
\end{tabular}

\section{KESIMPULAN}

Selama ini, perencana persediaan yang dilakukan oleh PT. XYZ terhadap permintaan konsumen hanya berdasarkan pada perhitungan kualitatif (insting) saja. Hal ini menyebabkan terjadinya penumpukan barang atau kekurangan barang persediaan akibat adanya ketidaksesuaian antara jumlah barang yang masuk dengan jumlah barang yang keluar. Penumpukkan barang akan meningkatkan biaya simpan, sedangkan kurangnya persediaan barang mengakibatkan konsumen beralih ke distributor lain. Untuk membantu PT. XYZ dalam meramalkan permintaan, maka dilakukan dengan analisis Metode SMA, DMA, SES, DES, Siklik, Linier, dan Kuadratik. Penentuan metode peramalan dibedakan menurut jenis barang karena mempertimbangkan error terkecil dari setiap metode jika digunakan pada setiap jenis barang. Berdasarkan analisis, terdapat 6 permintaan jenis barang yang sebaiknya diramalkan menggunakan Metode Linier, yaitu BD121183ST, BD481226ST, EXH1123AKCA, PA120468ST, PA12039IN, dan PA120322IN. Permintaan 4 jenis barang sebaiknya diramalkan menggunakan Metode Kuadratik, yaitu 
EXU1212AXBL, EXH2550ACBR, EXS4040BMJC, dan EX9055AXBL. Sedangkan peramalan jenis barang EX0560AKWH menggunakan Metode Simple Moving Average (SMA).

\section{DAFTAR PUSTAKA}

[1] P. Kotler, dan K. L. Keller, Manajemen Pemasaran 13rd edition, jilid 1, Jakarta: Erlangga, 2009.

[2] F.A, Reicita, "Analisis Perencanaan Produksi pada PT. Armstrong Industri Indonesia dengan Metode Forecasting dan Agregat Planning", Jurnal Ilmiah Teknik Industri, vol. 7, no. 3, Oktober, pp.160-168, 2019.

[3] W.Kosasih, I.S. Kumala, dan Y. Salim, "Evaluasi Sistem Distribusi Industri Kecil Menengah Menggunakan Metode Forecasting dan Distribution Requirement Planning (Studi Kasus: CV. Mandala Citra Lestari Tangerang )", Jurnal Ilmiah Teknik Industri, vol. 5, no. 3, Oktober, pp.139-147, 2017

[4] S.Makridakis, S.C.Wheelwright, dan V.E.McGee, Metode dan Aplikasi Peramalan, Jakarta: Erlangga, 1999.

[5] J. Supranto, Metode Peramalan Kuantitatif, Jakarta: Rineka Cipta, 1993.

[6] Schroeder, Roger G, Operations Management: Contemporary Concepts, Irwin/ McGraw-Hill, 2000.

[7] E. Herjanto, Manajemen Operasi (Edisi 3), Grasindo, 2007.

[8] D.Wijayanto, Pengantar manajemen, Gramedia Pustaka Utama, 2013.

[9] Heizer,J. Render,B, Operation Management edisi 7, Buku 1, Jakarta: Salemba Empat, 2005.

[10] A.H. Nasution, dan Y. Prasetyawan, Perencanaan \& Pengendalian Produksi Edisi Pertama. Yogyakarta: Graha Ilmu, 2008.

[11] V. Gaspers, Production Plannig and Inventory Control, Jakarta: PT. Gramedia Pustaka Umum, 2004.

[12] Arsyad, Lincolin, Peramalan Bisnis, Edisi Pertama, Yogyakarta: Universitas Gajah Mada, 2001. 